811.163.41'366.58:811.133.1'366.58

https://doi.org/10.18485/sj.2019.24.1.11

ВЕРАН Ј. СТАНОЈЕВИЪ *

Универзитет у Београду

Филолошки факултет

ЉУБИЦА 3. ЂУРИЪ ${ }^{* *}$

Универзитет у Београду

Филолошки факултет
Оригинални научни рад Примљен: 09. 10. 2018. Прихваћен: 15. 01. 2019.

\title{
АСПЕКАТ КАО ФАЗНА КАТЕГОРИЈА И РЕЗУЛТАТИВНОСТ У ФРАНЦУСКОМ И СРПСКОМ ЈЕЗИКУ ${ }^{* * *}$
}

Полазећи од концепције глаголског вида као фазне категорије, по којој се вид третира као граматички или граматикализован израз фазе на којој је комуникативни фокус, у раду испитујемо разлике између француског и српског језика у погледу маркирања постфиналне фазе глаголске радње тј. резулативности. У оба језика се резултативност изражава сложеним глаголским формама, а разлике добрим делом произилазе из разлика у начинима кодирања глаголског вида у француском и у српском, утолико пре што се у српском резултат глаголске радње може изразити не само перфективним, него и имперфективним видом. Циљ нам је да упоредимо, с једне стране, начине изражавања резултативности у два језика и, с друге стране, разлике (семантичке и/или прагматичке) у оквиру саме категорије резултативности, које могу бити основа за издвање поткатегорија овог типа лингвистичког значења. Рад заснивамо на Ветовом приступ аспекту као фазној категорији, који се може применити не само на језике у којима вид

*veranva@gmail.com

**1jubica.djuric1@gmail.com

*** Овај рад је настао у оквиру пројекта бр. 178014, Динамика структура савременог српског језика, који финансира Министарство просвете, науке и технолошког развоја Републике Србије. 
није морфологизован (нпр. француски), него и на језике у којима глаголски вид то јесте, као што је случај са словенским језицима, укључујући и српски.

Кључне речи: резултативност, имперфективност, перфективност, француски језик, српски језик

\section{1. О АСПЕКТУ КАО ФАЗНОЈ КАТЕГОРИЈИ}

Ослањајући се на аспектуални приступ Дика (Dik 1997) и Вета (Vet 2010), глаголски вид третирамо као фазну категорију, а резултативност као видску информацију у којој је комуникативни акценат на резултативном стању које произилази из радње означене предикатом. ${ }^{1}$ Наиме, теоријски се свака радња најпре може поделити на три сегмента, тј. на три фазе, а то су: почетна, медијална и финална фаза глаголске радње. У зависности од природе саме радње (тј. од лексичког значења глагола, које поред осталог садржи и подататке о инхерентној (не)ограничености (тј. теличности односно ателичности), затим о дуративности или пунктуелности, те динамичности или статичности), медијална фаза не мора увек бити присутна. Дуративни глаголи, било да су они ателични (нпр. читати, пливати, трчати, спавати и сл.) или телични ${ }^{2}$ (прочитати, отрчати, препливати, итд.) имају све три фазе. Уз теличне-тренутне глаголе (по Вендлеру achievements), као што су: експлодирати, убости, родити се, умрети итд., медијална фаза је одсутна па иницијална и финална фаза радње коинцидирају. Поменуте три фазе глаголске ситуације (Е) могле би се шематски представити на следећи начин:

(1)<smiles>C=I[AlH][In]</smiles>

У српскоме, као језику са морфологизованим глаголским видом, изражавају се већ на нивоу глаголске лексеме: а) медијална фаза (несвршеним глаголима), б) глобално све три фазе радње, тј. I+II+III (и то перфективним дуративним глаголима, као што су, на пример, прочитати, написати, препливати итд.), в) глобално само иницијална и финална фаза које коинцидирају (нпр. експлодирати, заболети, умрети итд). Перфективност се семантички, а у духу фазног приступа глаголском виду, може схватити као глобално пред-

${ }^{1}$ Под глаголском ситуацијом подразумевамо не само глаголску радњу као такву, него и стања ствари која евентуално претходе или следе самој радњи (Dik 1997 : 236-243, Vet 2007, Vet 2010).

${ }^{2}$ Ателични, тј. инхерентно неограничени глаголи одговарају, углавном, српским имперфективним глаголима, док телични тј. инхерентно ограничени глаголи одговарају, по правилу, перфективним глаголима. Међутим, има и изузетака у смислу да постоје перфективни глаголи који су ателични, на пример, поседети, одспавати, одремати. Наиме, ови глаголи, иако означавају свршене радње, могу се комбиновати са одредбама за трајање као индикаторима за ателичност у српском, као што су: десет минута, два сата и сл. (в. Станојевић 2012). 
стављање глаголске радње, глобално у смислу да су: или све три фазе, тј. целина радње у комуникативном фокусу, или су то само иницијална и финална фаза које коинцидирају, будући да се конципују као тачке. У реченици Марко је прочитао књигу комуникативни фокус је на целини радње која укључује не само фазу њеног одвијања него и иницијални и финални моменат радње. Имперфективност је фокусирање на медијалну фазу радње, па се тада радња конципује као неограничена, тј. без сагледавања њених стварних граница (читати, трчати, пливати...). На пример, у реченици Марко чита комуникативни фокус је на интервалу који се налази између почетне и финалне тачке радње читати, али се ове тачке не узимају у обзир при изрицању поменуте реченице. С друге стране, у реченици Бомба је експлодирала, комуникативни фокус је на тренутку који функционише истовремено као почетак и као крај саме радње, а која, будући да је тренутна, нема медијалну фазу.

Међутим, у неким језицима поред три основне фазе глаголске ситуације могу се изразити и претпочетна, као и постфинална фаза, будући да се у комуникативном фокусу могу наћи и стања ствари која претходе, као и стања ствари која следе извршеној глаголској радњи. Дакле, теоријски је могуће изразити укупно пет фаза глаголске радње и то: претпочетну, почетну, медијалну, финалну и постфиналну фазу. Шематски се ово може представити на следећи начин:

(2) .....пре I..[ I.....ІІ....III].....после III...... ${ }^{3}$

$\mathrm{E}$

За форме које означавају претпочетну фазу (тј. 'пре I' у шеми под бр. 2), каже се да изражавају тзв. проспективни аспекат, док се за оне које означавају постфиналну фазу (тј. 'после III' у шеми под бр. 2) каже да означавају резултативни аспекат. ${ }^{4}$

\section{2. ОД ФРАНЦУСКОГ ДО СРПСКОГ: РЕЗУЛТАТИВНОСТ И ПРОСПЕКТИВНОСТ КАО АСПЕКТУАЛНА ЗНАЧЕЬА}

У романистичкој лингвистичкој литератури (Verkuyl et al. 2004), термини проспективност и резултативност односе се на специфична видска значења неких глаголских облика и глаголских перифраза. Резултативност се као могући значењски ефекат финитних (али и неких инфинитних глаголских облика) везује за употребе сложених глаголских времена, док се проспективност приписује као могућ аспектуални ефекат перифрастичном футуру, тј. блис-

\footnotetext{
${ }^{3}$ Погледати Станојевић 2011.

${ }^{4}$ Неки аутори, као Кодал и Русари, резултативни аспекат сматрају обликом граматичког аспекта, за који се у литератури користи термин 'view point aspect' (Caudal and Roussarie 2006: 14).
} 
ком будућем времену (futur proche). На пример, у реченици On dirait qu'il va pleuvoir, у којој се уместо перифрастичног футура (познатијег у граматикама као future proche) не може употребити прости футур (future simple), будућа радња се саопштава с погледом на неко стање ствари актуелно у моменту говора (нпр. нагло захлађење, облаци на небу, ветар који најављује промену времена и сл.). Наиме, с перифрастичним футуром акценат се може ставити и на неко стање ствари актуелно у моменту говора које нам омогућава да тврдимо да ће се нешто десити. Оваква употреба перифрастичног футура могућа је ако претпоставимо да је ова футурална формација у стању да уведе у дискурс не само будућу радњу него и стање ствари које јој претходи, а то је заправо претпочетна фаза радње. У француском, за разлику од српског, граматикализовани су како резултативност тако и проспективност, док је у српском граматикализована само резултативност, док се проспективност сигнализује искључиво контекстуално.

\section{1 Резултативност у француском}

Нужан услов за испољавање резултативности у француском језику јесте употреба сложених глаголских облика, при чему у фокусу није сама радња него последице настале њеним извршењем, које су актуелне у неком временском моменту, који може бити, зависно од глаголског времена, или моменат говора или неки други временски моменат. У следећим примерима употребљена су четири сложена временска облика глагола partir („отићи”) у француском (перфекат, плусквамперфекат, антериорни перфекат и антериорни футур), при чему парафразе сваког од њих, које наводимо у заградама, указују на релевантно стање као резултат радње означене глаголом partir (= être absent).

(3) Il est parti. (= il est absent)

(4) Il était parti. (= il était absent)

(5) Il fut parti. (= il fut absent)

(6) Il sera parti. (= il sera absent)

Облик глагола être указује на позицију временске перспективе, тј. момента у односу на који се радња локализује у време. Са презентом, простим футуром и аористом перспектива је у моменту говора (il est parti / il fut parti / il sera parti), ${ }^{5}$ док је са имперфектом глагола être перспектива у прошлости (il était parti). Одмах треба напоменути да је употреба сложених глаголских облика

${ }^{5}$ Претпостављамо, по угледу на Вета (Vet 2010), да сложени временски облици који се заснивају на презентској морфологији (перфекат и анериорни футур), али и антериорни перфекат (као морфолошки специфична форма будући да се гради од аориста помоћног глагола), имају перспективу у моменту говора, док је код облика који се заснивају на имперфекатској морфологији (плусквамперфекат и кондиционал перфекта) перспектива у прошлости. 
(тј. времена), нужан, али не и довољан услов за изражавање резултативности у француском. Наиме, сви наведени облици осим антериорног футура акценат могу ставити и на саму радњу, и то, пре свега, ако су праћени неком одредбом за темпоралну локализацију: Il est/était parti à 5 heures. Антериорни футур и антериорни перфекат увек изражавају резултативност.

Неке реченице су двосмислене управо у погледу могућности да се њима означене радње конципују догађајно или резултативно. У примерима (7) и (8) акценат може бити, зависно од контекста, било на симултаности две прошле радње, било на симултаности резултативних стања које ове радње производе, с тим што се, у овом другом случају, с перфектом у примеру (7) јавља значење понављања две садашње ситуације („кад год је Пол ту, Марија је напољу”) док се с плусквамперфектом у примеру (8) понављање две исте ситуације дешава у прошлости („кад год је Пол био ту, Марија је била напољу”).

(7) Quand Paul est rentré, Marie est sortie.

(8) Quand Paul était rentré, Marie était sortie. ${ }^{6}$

Међутим, са антериорним футуром у истом контексту нема двосмислености, будући да је са њим акценат искључиво на постфиналној фази радње. Наиме, у примеру под бр. 9) на снази је искључиво симултаност два резултативна стања у будућности:

(9) Quand Paul sera rentré, Marie sera sortie. (= Quand Paul sera là, Marie sera absente.)

\subsection{1 Инвентар сложених форми за изражавање резултативности у француском}

Сви сложени глаголски облици у француском могу изразити разултативност, с тим што неки од њих, у зависности од контекста, могу означити и догађајност, тј. комуникативни фокус могу ставити и на радњу. У следећој

${ }^{6}$ У српском језику нема двосмислености у контекстима у којима с перфектом и плускамперфектом у француском има, као што су то клаузе са везником quand: Quand Paul est rentré, Marie est sortie. ('Кад се Пол вратио, Марија је изашла'). Хабитуална интерпретације реченице која подразумева понављање два симултана стања ('Кад год је Пол ту, Марија је напољу') није доступна у српском, иако узети засебно у перфекту ови глаголи могу означити резултативност: Видим да се Пол вратио (= ту је). Видим да је Марија изаила (= напољу је). Исто важи и за плусквамперфекат. Наиме, реченица Quand Paul était rentré, Marie était sortie, с резултативним значењем оба плусквамперфекта, може имати хабитуалну интерпретацију (понављање два симултана стања у прошлости), док одговарајући пример на српском нема ову могућност. Наиме, реченица Кад се Пол био вратио Марија је била изашла., може имати само догађајну интерпретацију. Питање зашто је то тако, остављамо за сада отвореним. 
табели представљамо дистрибуцију семантичких ознака за догађајност и за резултативност према глаголском времену: ${ }^{7}$

\begin{tabular}{|l|c|c|}
\cline { 2 - 3 } \multicolumn{1}{c|}{} & догађајност & резултативност \\
\hline Перфекат (раssé composé) & + & + \\
\hline Плусквамперфекат (plus-que-parfait) & + & + \\
\hline Антериорни перфекат (passé anterieur) & - & + \\
\hline Антериорни футур (futur antérieur) & - & + \\
\hline Блиско прошло време (passé recent) & + & + \\
\hline $\begin{array}{l}\text { Блиско прошло време у прошлости } \\
\text { (раssé récent du passé) }\end{array}$ & + & + \\
\hline Сложени инфинитив (infinitif passé) & - & + \\
\hline
\end{tabular}

\section{2 Услови испољавања резултативности}

Према Анити Митвох (Mittwoch 2008: 328), један од првих услова испољавања резултативности јесте да предикат буде теличан и транзиционалан. Предикат мора бити теличан зато што радња мора бити завршена да би могло наступити стање као њен резултат. Предикат мора бити транзиционалан, тј. мора упућивати на радњу која је по својој природи таква да након њеног извршења наступа неко стање које се разликује од стања које је било на снази пре него што је радња извршена (Vet 1980).

Да ли предикат има резултативно читање види се из допунске клаузе иза неког глагола перцепције (видети, чути) у презенту.

(10) Je vois que tu as fermé la porte. $\rightarrow$ Je vois que la porte est fermée.

Такође, резултативно читање искључује употребу квантификатора, тј. израза којима се означава понављање радње:

(11) Je vois que tu as fermé la porte quatre fois. $\rightarrow / \rightarrow *$ Je vois que la porte est fermée quatre fois.

Резултативно читање искључује употребу прилога за начин који модификују догађајну компоненту евентуалности означене предикатом:

(12) Je vois qu'il a vite fermé les fenêtres. $\rightarrow / \rightarrow *$ Je vois que les fenêtres sont vite fermées.

${ }^{7}$ Уз сложене глаголске облике, у табели фигурирају и перифрастичне форме за изражавање блиске прошлости пошто су и оне у стању да поред радње означе и резултативно стање. 
С друге стране, резултативност није инкомпатибилна са прилозима за начин који модификују резултативну компоненту радње, тј. њену постфиналну фазу, односно резултат који је извршењем радње настао. Такви се прилози у литератури називају резултативни адверби (Bonami et al. 2004: 179):

(13) Je vois qu'il a fermé les fenêtres hermétiquement. $\rightarrow$ Je vois que les fenêtres sont fermées hermétiquement.

\section{3 Резултативност српског перфекта и глаголски вид}

У српскоме је језику глаголски вид морфологизован, што значи да се испољава кроз опозицију између перфективних и имперфективних глагола, који се групишу у тзв. видске парове глагола (изузимајући двовидске глаголе): ${ }^{8}$ читати - прочитати, купити - куповати, скочити - скакати, пливати - препливати, препливати - препливавати итд. То практично значи да се, гледано из перспективе аспекта као фазне категорије, у српском већ на морфолошком (деривационом) плану види да ли је акценат на медијалној фази, као код имперфективних глагола (читати, ходати, спавати, гледати) или се радња конципује глобално и то: а) било да су све три фазе рање у комуникативном фокусу (I+II+III): Прочитао/написао/скенирао је књигу и б) било да само иницијална и финална фаза коинцидирају (срести (се), родити се, експлодирати, заболети, убости...).

Међутим, као у француском, и у српском се комуникативни акценат с радње може преместити на постфиналну фазу, тј. на резултативно стање које извршена радња генерише. Овај ефекат постиже се употребом сложених глаголских облика, попут перфекта који, исто као и француски перфекат (passé composé), поред догађајног може имати и резултативно читање:

(14) Петар је изашао. = Петар није ту.

(15) Поштар је дошао. $=$ Поштар је ту.

(16) Марко је обукао моју кошуљу. =Марко носи моју кошуљу.

(17) Он је купио кола. $=$ Он има кола.

Ова својеврсна трансформација глаголске ситуације, где се комуникативни акценат са радње премешта на њен резултат, аспектуална је по природи и последица је употребе одговарајућих граматичких средстава, тј. комбинације 'помоћни глагол + радни глаголски придев'.

${ }^{8}$ Двовидски глаголи (ручати, jecmu, ....) не указују својом формом на тип глаголске ситуације коју означавају реченице у којима су употребљени, него се тек из синтаксичког контекста види да ли им је интерпретација перфективна или имперфективна. Јео је десет минута (имперфективно) - Јео је за десет минута (перфективно). 


\subsection{1 Резултативност и несвршени глаголски вид}

У до сада наведеним примерима употребљен је свршени вид. Дакле, сви глаголи су телични, тако да је један од нужних услова за резултативно читање задовољен. С глаголима несвршеног вида у перфекту резултативног читања нема (18-21): ${ }^{9}$

(18) Петар је излазио. $\rightarrow / \rightarrow$ Петар није ту.

(19) Долазио је поштар. $\rightarrow / \rightarrow$ Поштар је ту.

(20) Марко је облачио моју кошуљу. $\rightarrow / \rightarrow$ Моја кошуља је на Марку.

(21) Он је куповао кола. $\rightarrow / \rightarrow$ Он има кола.

Међутим, оваквим реченицама с имперфективним перфектом може се сугерисати индиректан резултат извршене радње:

(22) Петар је излазио. > Под је каљав.

(23) Долазио је поштар. > Писма су на столу.

(24) Марко је облачио моју кошуљу. > Изгужвана је.

(25) Он је куповао је кола. > Разуме се у куповину кола.

Интересантно је да се наведени примери (Петар је излазио, Долазио је nоштар, итд.) могу тумачити и као резултат нашег закључивања на основу неког стања ствари у тренутку говора (под каљав, писма на столу, изгужвана кошуља). Наиме, о самој радњи се може закључивати на основу таквог стања и то путем онога што Апотелоз назива абдуктивно резоновање (нпр. 'Под је каљав, сигурно је Марко излазио', Apothéloz 2010).

Међутим, ствари је могуће посматрати и другачије. Наиме, ако претпоставимо да су реченице означене имперфективним перфектом истините (Петар јесте излазио), онда се одговарајуће реално стање ствари (каљав под) може сматрати могућом последицом догађаја означеног реченицом Петар је излазио. Такве последице, које наводимо у примерима 22-25) иза симбола за прагматичку импликацију ( >) називамо индиректним резултатом радњи означених имперфективним перфектом.

\section{4 Семантичка и прагматичка резултативност и искуствени перфекат}

Могуће је разграничити две врсте резултативности: семантичку и прагматичку. Код семантичке резултативности на снази је директан резултат радње ('јака резултативност', Mittwoch 2008: 328), док је код прагматичке

\footnotetext{
${ }^{9}$ Напомињемо да је у примерима с имперфективним перфектом релевантно значење једнократне радње која се завршила у прошлости, а не радње у току, или радње која се понављала у прошлости.
} 
резултат индиректан ('слаба резултативност', Mittwoch 2008: 333), односно инференцијалан (Apothéloz 2010: 4). Другим речима, индиректни резултат радње инферира се на основу наших знања о свету. Перфекат несвршених глагола у српском језику може сигнализовати прагматичку, али не и семантичку резултативност. Ова последња могућа је искључиво са перфектом глагола свршеног вида.

Познато је да се имперфективни перфекат може употребити и за сигнализовање дезактуализације резултативног стања у прошлости, те да је у том случају еквивалентан плусквамперфекту (Танасић 1995: 395). Међутим, ако се у примерима (22-24) имперфективни перфекат може заменити перфективним плусквамперфектом (примери 26-28) и тиме сигнализовати да директни резултат није актуелан у тренутку говора (при чему, поништавање директног резултата не имплицира поништавање индиректног), у примеру (25) то није случај, на шта указује пример (29), у коме се перфекат не може заменити плусквамперфектом без последица по истиносне услове реченице :

(26) Петар је излазио. = Петар је био изашао. (И сада је ту.) $\sim>$ Под је каљав.

(27) Долазио је поштар. = Био је дошао поштар. (Поштар више није ту.) > Писма су на столу.

(28) Марко је облачио моју кошуљу. = Марко је био обукао моју кошуљу. (Моја кошуља није више на Марку.) > Моја кошуља је изгужвана.

(29) Он је (већ) куповао кола. $\neq$ Био је купио кола. (Сад нема кола) > Разуме се у куповину кола.

У примеру (29) имперфективни перфекат куповао је кола не значи да је разултативно стање 'имати кола' дезактуализовано, тј. нужно промењено у моменту говора. Имперфективни перфекат у овом примеру евентуално може значити, тј. прагматички инферирати да је у тренутку говора на снази индиректан резултат радње означене предикатом. Овај индиректни резултат може се тумачити као знање саговорника о неком стању ствари које је настало на основу неке у прошлости (из)вршене радње. Није важно када је радња вршена, нити колико пута, важно је да се некада у прошлости одиграла, и да је као последицу у саговорника утиснула неко искуство.

Ни у наредним примерима имперфективни перфекат не може се заменити плусквамперфектом без последица по значење реченице:

(30) Читао је Јаднике. $\neq$ Био је прочитао Јаднике. > Зна нешто о Јадницима.

(31) Губио је пасош. $\neq$ Био је изгубио пасош. $>$ Зна шта треба радити када се изгуби пасош. 
(32) Ломио је ногу. ₹ Био је сломио ногу. > Зна шта треба радити када се сломи нога.

(33) $(\mathrm{Beh)}$ се удавала. $\neq$ Била се удала. $\sim>$ Зна како је тешко организовати свадбу.

Дакле, јасно је да се перфекат несвршених глагола може употребити за сигнализовање дезактуализације резултативног стања у прошлости, али се мора нагласити да је у питању дезактуализација семантичког, директног резултата радње. Такође, треба истаћи да индиректни резултат може бити на снази у тренутку говора и поред тога што је директни резултат поништен. У том случају имперфективни перфекат семантички је еквивалентан плусквамперфекту одговарајућег перфективног глагола. Међутим, у случајевима у којима се перфекат имперфективног глагола не може заменити плусквамперфектом salva veritate, као у примерима (29-33), при чему се имплицира постојање индиректног резултата радње у тренутку говора, и то тако да је тај резултат неко знағе, искуство учесника у комуникацији, сматрамо да се ради о тзв. искуственом перфекту. Искуство се у том смислу може сматрати посебном врстом индиректног резултатата извршене радње.

Треба нагласити да глаголске радње у примерима (30-33) могу имати и друге индиректне резултате. У примеру (32), Ломио је ногу, индиректан резултат би могао бити чињеница да саговорник храмље. Међутим, у том случају, имперфективни перфекат био би замењив плусквамперфектом свршеног глагола, што би искључило искуствено читање.

У француском, као језику који нема морфологизован глаголски вид, и директна и индиректна резултативност (дакле, и искуство), изражавају се перфектом (passé composé), док се дезактуализација директног резултативног стања у прошлости, и самим тим и стављање ван снаге директног резултата у моменту говора, изражава, као и у српском, плусквамперфектом (plus-queparfait). Међутим, за разлику од француског, у коме се на основу контекста одређује да ли је у питању директна (семантичка) или индиректна (прагматичка) резултативност, у српскоме језику постоји граматичко средство којим се сигнализује да је на снази индиректан резултат радње. То средство јесте управо перфекат имперфективних глагола. ${ }^{10}$ Када имперфективни перфекат није могуће заменити српским плусквамперфектом, на снази је посебна врста индиректног резултата - а то је искуство.

Искуствени перфекат већ је обрађиван у стручној литератури. Испољава се под следећим условима (Mittwoch 2008: 326-327): 1) Евентуалност се морала десити барем једном до тренутка говора, није важно када, тако да је овај

${ }^{10}$ И то само онда када не сигнализује радњу у току. Но, та употреба имперфективног перфекта надилази оквире нашег рада. 
перфекат компатибилан са прилогом déjà (већ), као у примеру (34). 2) Како евентуалност мора бити поновљива, искуствена резултативност је, за разлику од семантичке, компатибилна с кванитификаторима често, увек, никад, четиpu пута итд. односно француским одговарајућим изразима souvent, toujours, jamais, quatre fois итд. (види пример 35).

(34) Je l'ai (déjà) écouté jouer du Chopin. = Слушао сам га (већ) како свира Шопена.

(35) J'ai passé cet examen quatre fois.

$=$ Полагао сам тај испит четири пута.

\section{3. ЗАКЉУЧАК}

Ако аспекат посматрамо као фазну категорију, резултативност се може схватити као фокусирање на постфиналну фазу радње. У француском, за разлику од српског, граматикализовани су како резултативност тако и проспективност (фокусирање на претпочетну фазу радње), док је у српском граматикализована само резултативност, а проспективност се сигнализује искључиво контекстуално. На морфолошком плану, резултативност се у оба језика изражава сложеним глаголским облицима, као што је перфекат у српском и у француском језику (passé composé). Резултативност може бити семантичка (фокусирање на директни резултат радње) или прагматичка, односно инференцијална (фокусирање на индиректни резултат радње). Искуствена читања како француског тако и српског перфекта могу се подвести под прагматичку резултативност. Међутим, за разлику од француског, у српскоме се, захваљујући морфологизованом глаголском виду, тип резултативности може сигнализовати граматичким средствима. Тако, изражавању семантичке резултативности погодује свршени вид у српском, а изражавању прагматичке - несвршени вид. Посебан вид прагматичког резултата јесте искуство. У случајевима када се не може заменити плусквамперфектом, имперфективни перфекат у српском упућује на искуство као индиректни резултат прошле радње.

\section{ЛИТЕРАТУРА}

Apothéloz, D., Nowakowska, M. 2010: La résultativité et la valeur de parfait en français et en polonais. Cahiers Chronos 21, 1-23.

Bonami, O., Godard, D., Kampers-Manhe, B. 2004: Adverb classification. In: Handbook of French Semantics (F. Corblin and H. de Swärt, eds.). Stanford: CSLI Publications, 143-184. 
Caudal, P., Roussarie, L. 2006: Brands of Perfects: Semantics and Pragmatics. In: Proceedings of the 2004 Texas Linguistics Society Conference (P. Denis, E. McCready, A. Palmer, B. Reese, eds.). Somerville, MA: Cascadilla Proceedings Project, 13-27.

Dik, S. C. 1997: The theory of Functional Grammar, Part 1: The structure of the clause. Berlin - New York: Mouton de Gruyter.

Mittwoch, A. 2008: The English Resultative Perfect and Its Relationship to the Experiential Perfect and the Simple Past Tense. Linguistics and Philosophy 31 (3), 323-351.

Verkuyl, H., Vet, C., Borillo, A., Bras, M., Le Draoulec, A., Molendijk, A., de Swart, H., Vetters, C., Vieu, L. 2004: Tense and Aspect in sentences. In: Handbook of French Semantics (F. Corblin and H. de Swärt, eds.). Stanford: CSLI Publications, 233-270.

Vet, C. 1980: Temps, aspects et adverbes de temps en français contemporain : Essai de sémantique formelle. Genève : Droz.

Vet, C. 2010: L'interprétation des formes composées. In : Interpréter les temps verbaux (N. Flaux, D. Stošić, C. Vet and P. Lang, eds.). Frankfurt : Peter Lang, 11-31.

Vet, C. 2007: The descriptive inadequacy of Reichenbach's tense system: A new proposal. Cahiers Chronos 17, 7-16.

Станојевић 2011: В. Станојевић, О резултативности у француском и у српском, у: Српски језик, књижевност, уметност (М. Ковачевић, ур.). Крагујевац: Филолошко-уметнички факултет, 159-170.

Станојевић 2012: В. Станојевић, Перфективност и теличност у српском са освртом на ситуацију у француском језику. Научни састанак слависта у Вукове дане, 41/1, 141-155.

Танасић 2005: С. Танасић, Синтакса глагола, у: Синтакса савременог српског језика: проста речениия (П. Пипер, И. Антонић, В. Ружић, С. Танасић, Љ. Поповић, Б. Тошовић). Београд: Институт за српски језик САНУ, Београдска књига; Нови Сад: Матица српска, $345-475$. 


\section{L'ASPECT EN TANT QUE CATÉGORIE DE PHASE ET LA RÉSULTATIVITÉ EN FRANÇAIS ET EN SERBE}

\section{Résumé}

Dans ce travail, nous examinons certaines différences entre le français et le serbe concernant l'expression de l'aspect résultatif. Ces deux langues ont en commun d'exprimer la résultativité par le recours à des formes verbales composées. Etant donné les différences d'encodage de l'aspect dans ces deux langues, nous avons particulièrement examiné le rôle de l'aspect imperfectif en serbe vis-à-vis de l'expression de l'aspect résultatif, ce qui nous a amené à examiner la distribution des deux types de résultativité, à savoir la résultativité sémantique et la résultativité pragmatique. Il s'avère qu'en français, l'expression d'un résultat indirect du procès (résultativité pragmatique) ne se fait que contextuellement, alors qu'en serbe le parfait imperfectif, qui, tout en étant inapte à l'expression d'un résultat direct (résultativité sémantique), semble dotée de la capacité à exprimer un résultat indirect. L'unique manière d'exprimer le résultat direct en serbe est d'utiliser l'aspect perfectif. Si le passé composé français dit d'expérience ainsi que son pendant serbe (le parfait d'expérience) peuvent désigner des états résultants, il s'agit, dans les deux cas, de la résultativité pragmatique.

Mots clés: résultativité, imperfectivité, perfectivité, le français, le serbe.

Veran J. Stanojević Ljubica Z. Đurić 